\title{
NEW TRENDS IN MARITIME TRANSPORTATION AND PORT ACTIVITY
}

\author{
VICENT ESTEBAN CHAPAPRÍA \\ Ports and Coastal Engineering, Universidad Politécnica de Valencia, Valencia, Spain
}

\begin{abstract}
The role of ports has changed and has become more complex. Ports play a relevant role in global economy. They connect modes of transport and usually they are the leaders in the logistics chain. New works in Suez Canal were in progress until August 2015. The expansion of the Panama Canal will finish this year. These new operational conditions allow for an improvement of international maritime transportation. The Suez Canal Corridor Area Project is a mega project in Egypt that was officially launched in August 2014. The project's aim is to increase the role of the Suez Canal region in international trading and to develop the three canal cities: Suez, Ismailia and Port Said. The importance of these actions changes in the new port cities and new trends and conditions in maritime transportation are discussed.
\end{abstract}

Keywords: maritime transportation, Panama Canal expansion project, ports, port cities, Suez Canal.

\section{INTRODUCTION}

The role of ports has changed and has become much more complex over time. Today, ports must be analysed on the basis of their role in the logistics or supply chains of which they form a part. The port must offer connectivity between the modes of transport in an environmentally integrated and respectful way (co-modality). Ports must provide infrastructure, facilities and handling equipment. Moreover, they must bridge the gap between modes of transport in terms of frequency, capacity and time. Ports are playing a relevant role in global economic activity and are directly affected and conditioned by its evolution and changes. This leading role of ports in the logistics chain plunges them into the mechanisms of the market, in terms of their influence and participation in the production and transportation processes. Changes in the mechanisms of production and transport and in logistics chains and their associated flows are of great importance to ports. Two main engines are driving these changes: technological changes and globalization. At the same time new conditions of maritime transportation have been implemented. But ports are also subject to more general tendencies from a political and social standpoint. In this sense, it is worth emphasizing the enormous impact of economic liberalization and deregulation of the economy and transport policies in the majority of countries over the past few decades. This has been a prime factor in encouraging the growing presence of private initiative in ports and the evolution of management models known as service port, tool port, landlord port and private ports.

Numerous canals and waterways in the world improve the international maritime transport. They are arteries of navigation. But, at the same time, they limit international shipping due to their geometrical and operational characteristics. Limitations derive from various definitions and characteristics of the vessels that can transit. The term 'Malaccamax' sets the dimensions of ships that can pass the Strait of Malacca, with a depth of $25 \mathrm{~m}$. This designation refers to large vessels, especially large bulk carriers and tankers that carry crude from Saudi and the Persian Gulf to China. Similarly, the concepts of Seawaymax, Suezmax and Panamax, set the maximum size of ships able to navigate through the Saint Lawrence Seaway and the Suez and Panama canals, respectively. Instead, a Capesize vessel exceeds the maximum geometry 
of these last two channels and, consequently, requires navigating around the Cape of Good Hope or Cape Horn.

Improvement works on these ways and channels have led to an evolution of these concepts over time. Suezmax vessels were limited both in the draft, which after the expansion works implemented in 2009 went from 18 to $20 \mathrm{~m}$, and in headroom limitation imposed by the existing bridge, which is $68 \mathrm{~m}$. In early August 2014 the most recent work on improving the Suez Canal began. Saint Lawrence Seaway is another example. This channel connects the Atlantic and Lake Superior using a system of locks. It is managed jointly by Canada and the United States of America (USA) and is complemented by the Great Lakes Waterway. Proposals for its construction began in 1909, but clashed with the interests of the railway and the ports of the USA. In addition to replacing the system of canals, hydroelectricity generation also gave the project impetus. Its construction was finally approved in 1954, when Canada unilaterally declared its interest in taking the project forward. It was officially opened in April 1959 and the cost of the work amounted to 470 million US dollars, over $70 \%$ of which was paid by Canada.

International maritime transport has been growing over the past few decades. The Review of Maritime Transport (United Nations Conference on Trade and Development, UNCTAD) [1] established that the volume of world merchandise trade expanded in 2013, albeit at the modest rate of $2.2 \%$. The review also indicated some risks due to the fragile recovery of developed economies, the obstacles to growth in large emerging economies, and geopolitical tensions that may escalate. Measures to stimulate global growth were adopted in the Group of Twenty (G20) summit held in February 2014, especially concerning potential gains deriving from growing trade deals and initiatives, the improvements in South-South trade and investment relations, the rise in horizontal trade, growing consumer demand, especially in Western Asia and Africa, and the growth in minerals and resource-based exports.

\section{MAIN TRENDS IN PORTS}

The main trends (Estrada) [2] which currently have a direct or indirect bearing on the activity and development of ports are the following:

(i) Economic and international trade trends: production systems evolve towards a single global supply market, competition takes place at logistics chain level, long-term forecasts of continued growth in international and maritime trade due to globalization, etc.

(ii) Logistics and transport: strategic decisions regarding the supply, global vision of the chain and vertical integration, direct management of port terminals, presence in transportation corridors and inland terminals, decentralization of distribution networks, intermodal systems gain ever more ground, roads are increasingly congested and European policies are encouraging intermodal and sustainable transport systems.

(iii) Trends in maritime transport and vessels: transport keeps growing, with both vertical and horizontal business integration, increasing importance of container transfer and the growing presence of global stevedores, like Hutchison Port Holdings Limited, Dubai Ports World, Port of Singapore Authority and the Arnold Peter Møller-Maersk Group for instance, who manage more and more terminals and tend to develop network strategies, growth in vessel size and fleets. It seems that this growth will take place in the maximum- and medium-size ranges, especially in the case of container 
carriers. This growth may be even faster than we have thus far imagined. Maersk Line, for example, has recently announced its plans to build what will be the ten largest container carriers in the world, so-called Malaccamax 18,000 twenty-foot equivalent unit (TEU) capacity economy of scale, energy-efficient and environmentally improved class vessels. It should also be pointed out that these vessels bring in a $26 \%$ saving on the Europe-Asia route and a fuel saving as a result of the two-knot speed reduction compared to their predecessors. But it is not only container carriers that are growing; other vessels such as bulk carriers, cruise ships, etc., are following the same trend. As far as fleets are concerned, the last 20 years have seen a significant increase in deadweight tonnage, but this has not been so in the actual number of vessels; although there has been growth across all cargo types, the container fleet has experienced the greatest increase. However, as a consequence of the growth in average vessel size, the growth in the number of vessels has been smaller and in some cases has actually decreased, as is the case with general cargo vessels. Another consequence of the increase in container carrier size, especially at the top end, is the impact on transfer and the consequent rise in the number of transfer ports and in the volume of traffic through the existing ones, as well as in their associated feeder ports. Fierce competition has emerged between ports for this traffic, which subjects them to great stress and increases in the volume of traffic, as can currently be seen in the Western Mediterranean (Fig. 1).

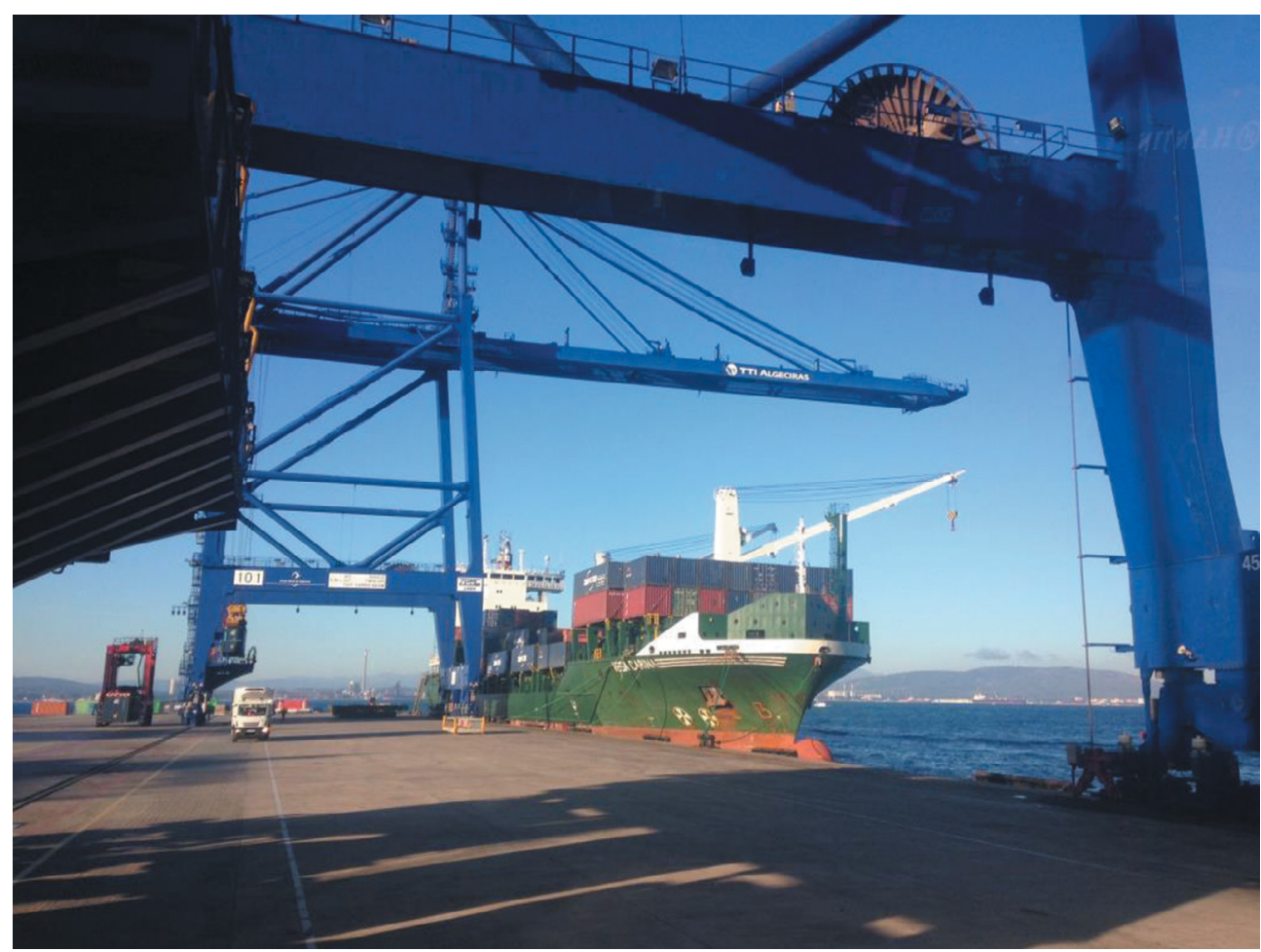

Figure 1: Container terminal in Algeciras port. 
(iv) Evolution of cargoes and their form of presentation: changes in the presentation of cargoes, particularly as a result of the increased containerization. In the case of containers, the concern is always to reduce the cost per tons, which leads to an increase in container size. There are already 45 and 48 foot containers in the market and bigger ones have been recently introduced.

(v) Trends in port information systems: ports are increasingly characterized not only by their role as transport facilitators in the physical sense, but also by being key elements in facilitating and sharing information related to their activity.

(vi) Effects of the existence of new maritime transportation routes and the improvement of existing ones: Panama Canal, Arctic thawing and the deepening of the Suez Canal, which will be analysed later.

(vii) Effects of sustainability policies and concern for the environment: new proposals have recently been considered in European Union transport policy (reduction in gasoline gallon equivalent, in the transport sector, reduction of $\mathrm{CO}_{2}$ from vessel fuel by 2050 , transfer to rail or sea by 2030, short sea shipping, etc.). Alternative power sources for vessels as well as for the port terminal's vehicles and mobile equipment, and environmental considerations are very important when it comes to decisions affecting planning, location, design, construction, operations and handling equipment in ports and terminals.

(viii) Safety and security: International Maritime Organization, United States Customs and Border Protection and the European Parliament and Council have imposed a number of security regulations on vessels and ports (Fig. 2).

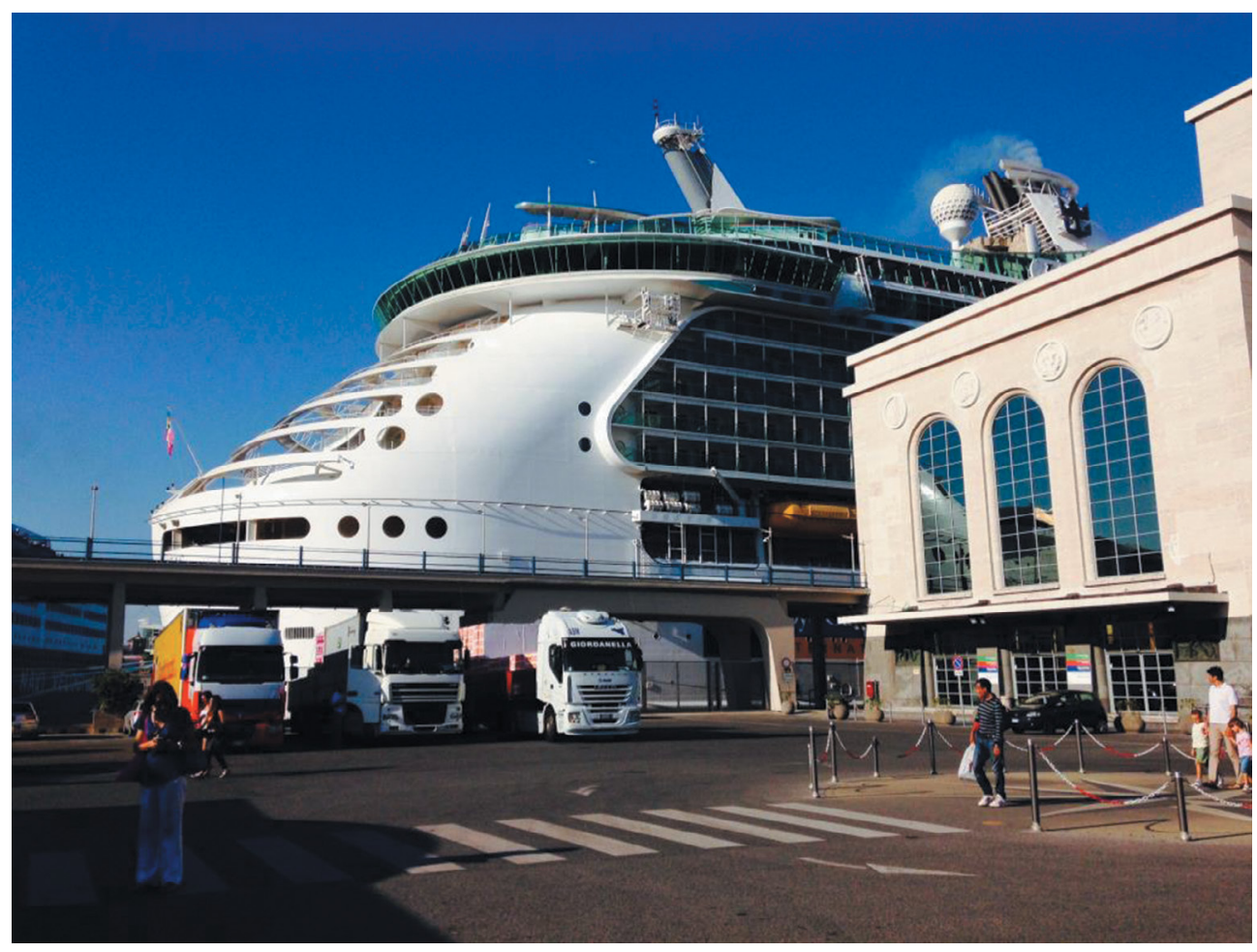

Figure 2: Cruise terminal in the port of Naples. 
Consequently, ports need to become more integrated in the logistic chains. Hinterland connectivity, efficiency and productivity of the port and the logistic chain as a whole, and the improvement and efficiency of the information and communication systems will be required. At the same time, technological advances should be expected in vessel management in the port, berthing and mooring, as well as in ship to quay transfer equipment. Safety and security will also be vital elements in the supply chain.

\section{THE IMPORTANCE OF SUEZ}

In the last year new works have been promoted by the Egyptian government in the Suez Canal. These have led to improvement work on $72 \mathrm{~km}$, opening up the channel, in order to allow simultaneous transit of a larger number of vessels, doubling its capacity. The works involved the digging of a new $35 \mathrm{~km}$ route alongside the existing one and the widening and deepening of $37 \mathrm{~km}$ of the existing canal. The official estimate has assessed the cost of these actions to be $€ 7,400 \mathrm{M}$. The Suez Canal has reduced shipping distances and times. The Eurasian route, Singapore-Rotterdam passing through Suez, is 3,000 miles shorter than going around Africa. Considering an average speed of 15 knots, it means that navigation has been reduced by nine days, along with the logical reduction in transport costs. Every year, between about $7 \%$ and $8 \%$ of the total of the worldwide exchange of goods transits through the canal.

In the last decade the traffic through the canal has increased significantly, from 520 million tons in 2004 to 822 in 2014 (416 million tons north-south, and 406 in the opposite direction). North-south traffic has grown more than the reverse. Half of it is container traffic. The role of the channel and Egypt in the chain is extremely important, because of its location at the crossroads of the main east-west flows in the Northern Hemisphere, with ports and cities of great importance such as Port Said, Alexandria and Damietta, which have focused much of the investment in port infrastructure in the country. Transportation of oil and its derivatives, as well as the liquefied natural gas, have also increased in recent years. Since 2000 they have increased by $250 \%$ and $1,150 \%$, respectively.

Improvements to the Suez Canal can reduce the transit time of the boats from $18 \mathrm{~h}$ to $11 \mathrm{~h}$, and almost double the capacity of the seaway - from the 49 ships per day to the 97 planned for 2023. The estimate indicates that increased traffic will achieve double the income: from $€ 4,600 \mathrm{M}$ in 2014 to the $€ 11,680 \mathrm{M}$ calculated for 2023 . The construction, to be carried out by six foreign companies, was launched in 2014 in a ceremony where the Egyptian government reduced to one year the deadline of five years estimated by the international consultants, probably spurred on by the conclusion of the expansion work in Panama.

Investments have meant that Egypt is among the countries with the best performance and potential for improvement. The intervention on the canal is part of an economic development, especially in the transport sector and the maritime and port economy, whose main objective is to recover efficiency in international trade, as noted by UNCTAD and the World Bank (SRM) [3]. The channel now allows passage of larger vessels, 120,000-200,000 GRT.

\section{PANAMA, THE OTHER MAIN AXIS}

The role played by the Panama Canal in international maritime transport is well known. The Panama Canal Authority (ACP), has begun in 2000 a change of profile in the canal management. The ACP has focused on operational criteria and different services to international transport. In 2002, the ACP introduced changes in the toll system, leading to a strategy of market segmentation and price differentiation. The changes introduced by the new authority resulted in higher revenues for Panama. 


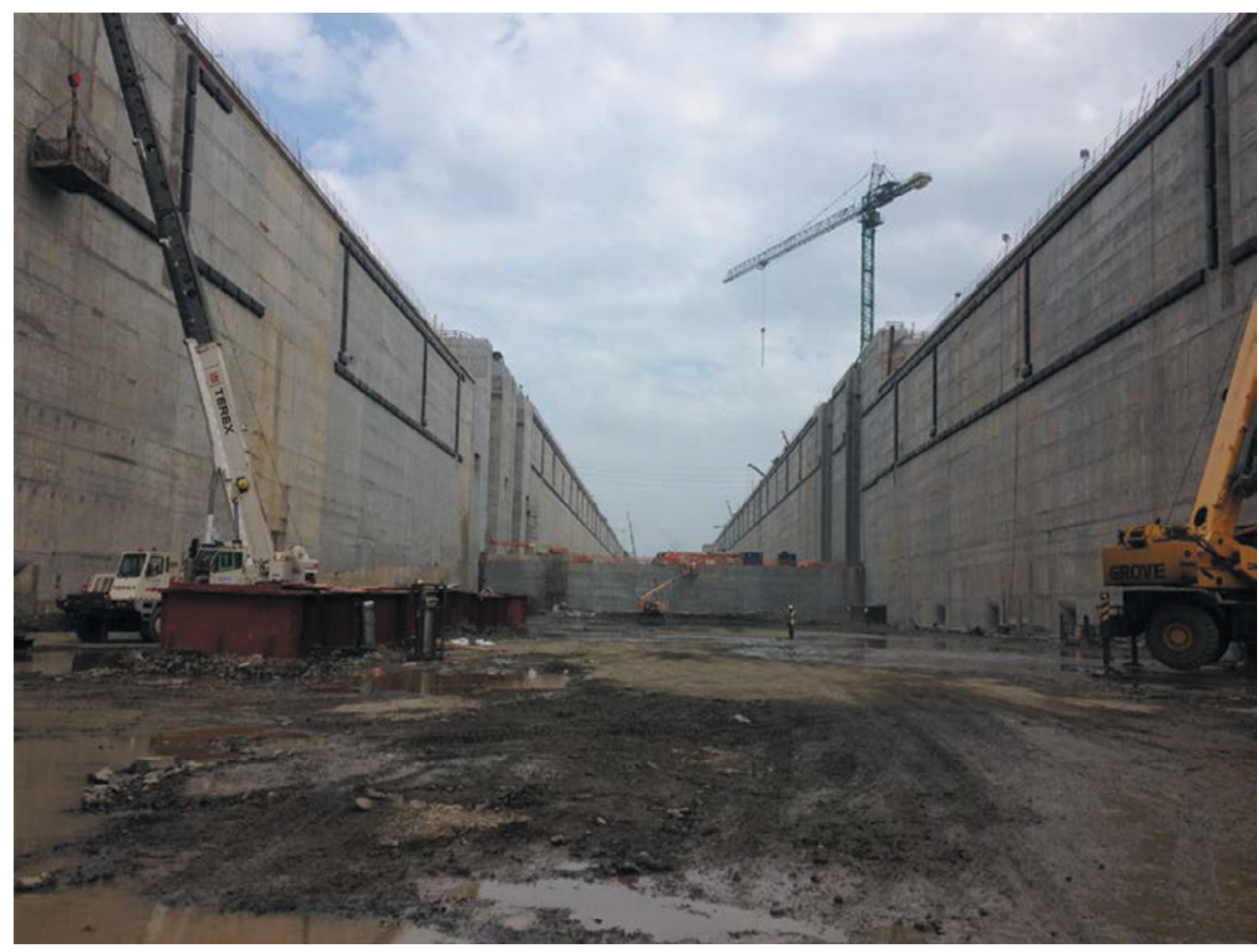

Figure 3: Third set of locks in Panama Canal expansion project under construction.

The new third set of locks in the Panama Canal expansion project is scheduled for April 2016. Debates and studies on the feasibility of building another canal through Nicaragua are still ongoing. A navigable route passing through the northwest Arctic and other intermodal channels, such as those in the Canada and the USA, as well as other ongoing studies in America (both the Central and the South), have also been debated and analysed. In the recession that began in 2008, when the Panamanian authorities sought financing for expansion works, there were delays in the completion of the works. These delays have affected the canal, reducing the potential transits through it, which has been compounded by increased competition from the USA intermodal system. Traffic to the East Coast of the USA is decreasing, especially building materials, which have seen a contraction in demand in recent years because of the economic situation [4]. At the same time, some shipping companies have chosen to serve the East Coast of the USA with bigger ships from Asia through the Suez Canal (Fig. 3).

\section{NEW ROLES FOR EVERYONE?}

All these improvement works will have a huge impact on the development of world maritime routes, especially as regards container traffic and the ports concerned, particularly those on both sides of the North Atlantic [5]. It may also be expected that new 'round the world' services will appear. Although undoubtedly further ahead in time, the apparently unstoppable thaw of the Glacial Arctic Ocean will enable new and shorter routes to be established between Asia, America and Europe through the Arctic, reducing distances to and from the Pacific and encouraging the establishment and growth of new ports in the most northern reaches of the 
Northern Hemisphere. This could in turn affect the Panama Canal and Mediterranean routes and their associated ports. Although they are not a requirement for today's container carriers, new depths in the Suez Canal will enable the passage of vessels larger than those that the widened Panama Canal will be able to accommodate. This will facilitate the possibility of traffic from the Far East to the East Coast of the USA, in competition with the Pacific, which indeed is already happening to an extent.

Throughout history, conflictive situations, both because of politics and war, have immediate effects on consumption and transport. In the period of financial crisis, which started in 2008 , the expectation of growth in international shipping has been reduced. But also the areas of production have adapted their strategies. In China, for example, the 2011-15 five-year plan sets out four areas of action: economic restructuring, industrial reform, redistribution of income and environment. China has repositioned itself in the world, adopting production lines with more added value than previously, securing its supplies of raw materials and controlling the keys to commercial distribution.

The role of ports and cities, as well as the large arterial transport structures (Suez and Panama), has changed and will keep changing. The Panama Canal, which was initially of military strategic value, has evolved towards the provision of services and is now a source of wealth for the country, the region and America as a whole. Goods intended for countries on both the east and the west coasts of South America are linked to the Panama Canal. The dependence of the channel on the foreign trade of countries like Chile, Colombia, Ecuador and Peru is extraordinary. International waterways and ports must act as a source of savings for transport. But they must also act as distribution centres and malls that add value to the assets transferred. In fact, they relate strong economic dependencies of regional impact.

It is also important to improve competitiveness to understand the changes. The changes have to be considered not only from an economic point of view, but also from a social one. New strong and well-supported political and social currents play an increasingly important role. The proposals and responses of some municipal and regional governments and situations of conflict in the Mediterranean and in the political organization of large areas of the Middle East and Europe generate changes in demand, and demand for a better quality of life, beyond economic performance, profitability and competitiveness. Only a few countries have undertaken tasks of the adaptation, improvement and development of port facilities and intermodal key elements, including Egypt and Panama. The situation experienced in many countries in recent years has helped to maintain or postpone investments.

\section{TERRITORIAL CHANGES}

Along with the initiatives outlined, Egypt has designed a new plan for the Suez Canal: the 'Suez Canal Corridor Project Area' (SCZone). It is an investment plan whose main objective is the advancement of a centre of regional economic development. The plan includes the construction of industrial areas and is dedicated to logistics and research centres all along the canal. And, therefore, it is a plan that goes beyond intervention on the canal. SCZone performances are planned both in Port Said in the north, Ismailia due to its central position, and in Ain Sokhna on the Gulf of Suez. In all cases, there is space available and through a master plan two horizons were established: an intermediate one in 2030 and a final one in 2050. The plan aims to set up a new logistics and industrial area.

In Port Said, there are plans for the expansion of the existing port to reach a final capacity of 20 million TEUs in 2050. This is designed to act in a total area of 22,000 ha. Until 2015, the maximum capacity of Port Said was 3.3 million TEUs, but it has been expanded 
with a new terminal that provides an additional capacity of 5 million TEUs. Port Said container terminal, which operates full time and has been operational since 2004, serves transfer traffic in the Middle East. The concession for 49 years was awarded to Suez Canal Container Terminal and is minority owned by the Suez Canal Port Authority, the Egyptian National Bank and Egyptian small private investors. Port Said is obviously a core of national strategic development and SCZone intervention plans contemplate the provision of industrial equipment for the harbour and residential areas. The total area of intervention will be more than 4,000 ha, of which 800 will be used for residential and commercial use, providing enormous possibilities for intervention. Under the plan, Port Said will remain linked to the port of Ain Sokhna, on the south side, with a parallel track to the channel, and in the latter port a new container terminal will be developed to move up to 5.2 million TEUs, which will also be complemented with a new urban area. In the intermediate zone, in the vicinity of Ismailia, the construction of another residential area is also projected on an area of 670 ha (Fig. 4).

New port infrastructure in Panama has been considered, as well as opportunities to intervene in cities like Columbus, Puerto Sherman and Fort San Lorenzo, reversing complex socio-economic situations. Interventions in port cities will continue changing the use of many areas, designing rearrangements, etc., always under the principles of accessibility and sustainability. But the risks of relocation and derivatives expiration volatility and market decisions require some caution and good planning, while other areas are reducing their activity. The creation of intermodal infrastructure and distribution elements certainly will set up a new framework where the situation of economic growth will recover. Processes, both as areas of cultural identification and social changes, offer opportunities in the territory, cities and ports.

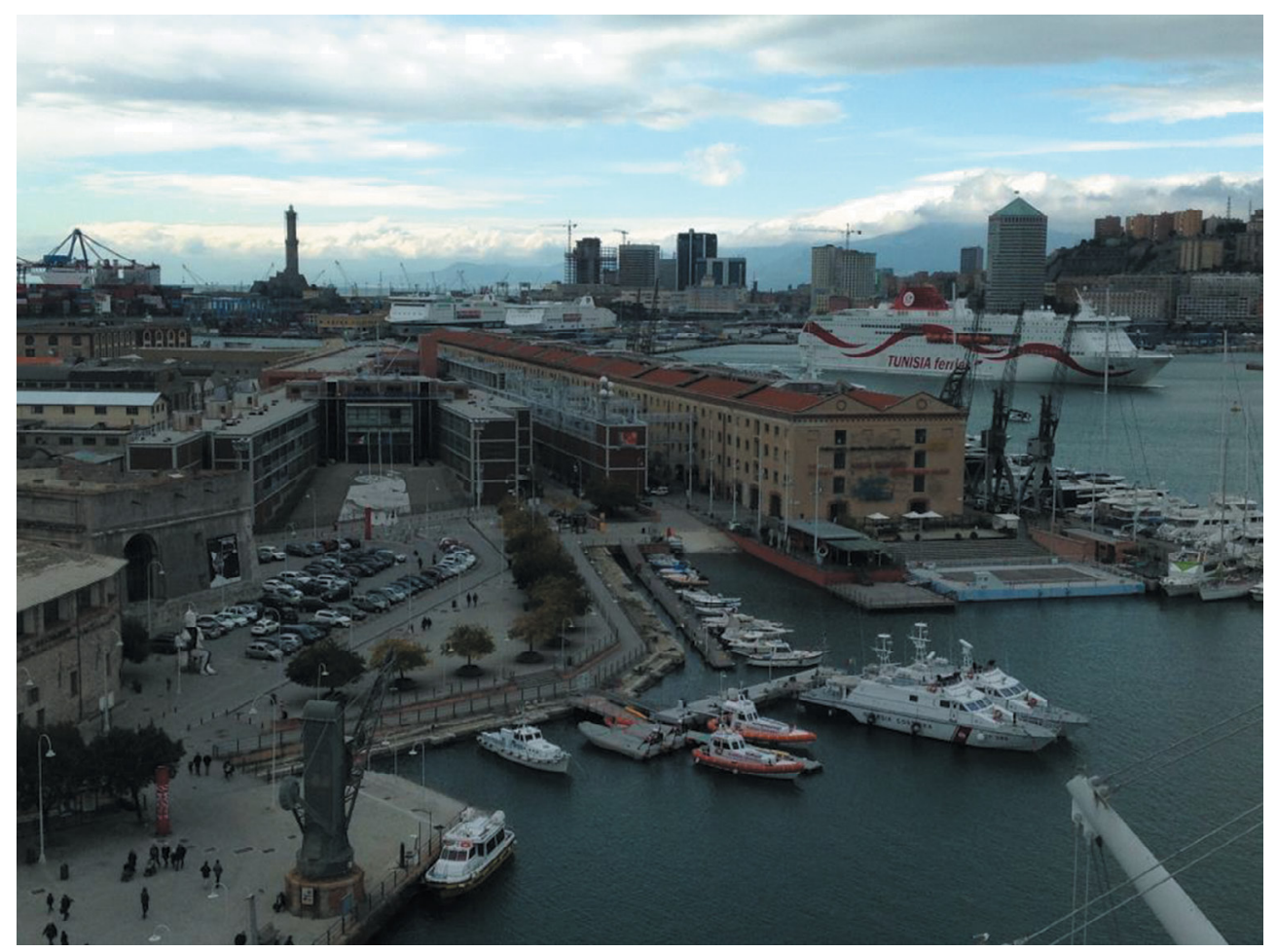

Figure 4: Changes in inner areas in ports and cities. The case of Genoa. 


\section{CONCLUSIONS}

New trends and changes in maritime transport and ports are very relevant and are always ongoing. Territorial changes and effects in the new port cities have also been registered. The main current trends in maritime transportation and ports have been established concerning economic and international trade trends, logistics and transport, maritime transport and vessel conditions, evolution of cargoes and their form of presentation, trends in port information systems, effects of the existence of new maritime transportation routes and the improvement of existing ones, and sustainability policies and concern for the environment and safety and security. The main ports need to become more closely integrated in the logistics chains, and good hinterland connectivity, efficiency and productivity, and an improvement in the efficiency of information and communications systems will be constantly required.

\section{REFERENCES}

1. United Nations Conference on Trade and Development UNCTAD, Review of Maritime Transport 2014. UNCTAD/RMT/2014. United Nations Publication, ISBN 978-92-1112878-9, 2014.

2. Estrada, J.L., The port city of the XXIst century. New challenges in the relationship between port and city. ed. RETE, Association for the collaboration between ports and cities. Venezia, ISBN 978-88-906509-0-1, 2015.

3. SRM-Maritime Economy, Gli effetti economici del raddoppio del Canale di Suez sul traffici del Mediterraneo, available at http://www.srm-maritimeconomy.com/, 2015, (accessed 18 November 2015).

4. Sabonge, R. \& Sánchez, R.J., Los 100 años del canal de Panamá: antecedentes, desarrollo y potencial futuro. CEPAL. Bul. FAL, Edition No 334 - N. 6, 2014.

5. Gálvez, C., La ampliación del canal de Panamá y sus efectos en el comercio marítimo internacional. Revismar, February 2011, Chile. 